Kritische bibliografie

\title{
AFGUNST EN SCHAARSTE
}

\author{
Jacques De Visscher
}

Hans Achterhuis, Het rijk van de schaarste. Van Thomas Hobbes tot Michel Foucault. Baarn. Ambo, en Schoten, Westland, 1988, 365 blz., 890 Bfr., ISBN 90 26308485

Hans Achterhuis, universitair docent sociale filosofie in Amsterdam en bijzonder hoogleraar wijsbegeerte aan de Landbouw Unvirsiteit Wageningen, heeft een originele geschiedenis van de wijsbegeerte geschreven. We kennen de gebruikelijke handboeken waarin verteld wordt wat de filosofen vanaf Thales tot Rorty 'allemaal hebben gezegd'. De auteurs van zo'n handboeken wekken de indruk dat ze feilloos alles kennen en dat ze zonder noemenswaardige problemen het denken van Thomas van Aquino of van Hegel op enkele bladzijden kunnen samenvatten. Helaas overtuigt zo'n boek alleen de naieve en onwetende lezer; de andere, gewaarschuwde of geïnitieerde lezer, die zich wat heeft ingelaten met bijvoorbeeld Descartes, Bergson of Merleau-Ponty, ontdekt echter al te gauw grove schematiseringen, onjuistheden of onvergeeflijke lacunes in de weergave van het werk dat hij wat beter kent. Maar soms moet zo'n lezer ook toegeven dat andere behandelde filosofen, die hij ook wat kent, toch niet zo slecht worden gepresenteerd. Kortom, de handboeken geschiedenis van de wijsbegeerte, geschreven door één enkele auteur vertonen gebreken en eenzijdigheden. De twee bekende voorbeelden die in het $\mathrm{Ne}$ derlands zijn vertaald, die van Bertrand Russell en van Hans Joachim Störig, zijn zo vaak het object van bezwaren en kritiek geweest. Maar tegelijk moet men bekennen dat ze hun verdiensten hebben, dat ze menig beginnende lezer hebben geholpen, en dat ze daarenboven nog steeds niet zijn vervangen. Er is zelfs meer : leraren en uitgevers beginnen zelfs eenvoudiger en minder goede alternatieven voor te stellen.

Zo'n conventioneel handboek heeft Hans Achterhuis nu juist niet gepubliceerd, al komen de filosofen van Plato tot Rawls wel aan bod. Maar in de eerste instantic heeft hij een duidelijk thema gekozen, met name de schaarste, en heeft hij zich grotendeels beperkt tot slechts enkele filosofen, Thomas Hobbes, John Locke, Jean-Jacques Rousseau, Karl Marx en Michel Foucault, die hij primo uit eerste hand kent, secundo zonder de pretentie volledig te zijn uitvoerig bespreekt, tertio 
laat omzwermen door een hele scala van andere filosofen, waardoor een permanente dialoog en discussie ontstaat. Daarenboven confronteert Achterhuis zijn vijf wijsgeren haast permanent met elkaar en toetst ze tenslotte aan de centrale gedachte van een zesde wijsgeer, René Girard, die dus nagenoeg op elke bladzijde expliciet of impliciet als de demonische bewaker van het systeem van de 'mimetische begeerte' om de hoek komt kijken.

In zijn inleiding schrijft de auteur dat zijn boek de pretentie heeft een inleiding te bieden op het denken van de filosofen die hij - niet volledig - behandelt; verder laat hij opmerken dat gedeelten van zijn werk regelrecht voortkomen uit een inleidend college in de sociale filosofie. Eigenlijk ben ik wel blij dat dit niet helemaal zo uitkomt. De titelbladzijde bevat gelukkig niet de vermelding 'inleiding' en verder bekommert Achterhuis zich ook niet zo erg om al dat 'inleidend' gedoe, zelfs al kleedt hij het denken van de filosofen in een heel rudimentaire biografische schets in en zijn er tenslotte enkele plaatjes die een aantrekkelijke indruk moeten wekken. Nogmaals, zo maar een inleiding is Het rijk van de schaarste niet, en dit is ook niet nodig. Er zijn helaas in ons taalgebied al te veel inleidingen tot de wijsbegeerte geschreven. Het is zo wat een Hollandse kwaal dat men steeds maar opnieuw inleidingen schrijft - er publiceerde zelfs iemand een 'gemakkelijke' inleiding - alsof het nu eens echt niet ernstig mag worden. Ik weet wel : uitgevers sturen op zo'n inleidingen aan; zij mikken op het schoolpubliek en op de verplichte afname door studenten. Bijgevolg mag niets grondig heten, want dan loopt men het risico geen publiek voor zijn werk te vinden. Uitgevers willen immers verkopen en liefst nog een vlugge omzet ook. Vandaar dat ze eerder dunne boekjes uitgeven, zonder al te veel 'moeilijke' woorden of 'ingewikkelde' redeneringen en zinsconstructies. Een moeilijk boek past niet op de boekenmarkt of moet door een of andere instantie worden gesubsidieerd; desnoods moet de auteur mee investeren. Dit is nagenoeg de regel. Er zijn echter uitzonderingen - gelukkig! Het rijk van de schaarste is nu wel geen moeilijk werk, wel een lijvig boek dat tegelijk historisch en systematisch een thema uitwerkt. Van de lezer verwacht het boek een inspanning opdat hij de articulaties van Achterhuis tot het einde toe zou willen blijven volgen.

Wat toont de auteur nu aan ? Zijn stelling is dat men in het verleden onvoldoende over het fenomeen van de schaarste heeft nagedacht, dat men de schaarste te weinig heeft onderkend en dat men de dynamiek van de schaarste te eenzijdig heeft geïnterpreteerd. "Als er al over schaarste gedacht wordt, gebeurt dat vaak in het bekende kader van een vooruitgangs- en ontwikkelingsideologie. Er wordt dan gesteld dat de vroegere schaarste op veel gebieden overwonnen zou worden om in de moderne tijd te worden vervangen door zoiets als overvloed. Schaarste wordt dan nog aanwezig geacht in onontwikkelde of onderontwikkelde gebieden, zij wordt in verband gebracht met honger in de Sahel of armoede in India. Met tech- 
nische middelen zou ze in de toekomst ook daar overwonnen kunnen worden" (blz. 12-13). Hans Achterhuis toont in zijn boek precies het tegenovergestelde aan. Het is voor hem duidelijk dat de moderne maatschappij de schaarste niet heeft overwonnen, maar wel heeft gecreckerd. Als men de problematiek op wereldschaal bekijkt, kan men onmogelijk overvloed zien, integendeel, de schaarste breidt zich steeds maar verder uit. Niet alleen zijn heel wat gemeenschappen in de landen van de Derde Wereld van 'self-sufficiency' naar het niveau van de honger en de armoede gevallen, maar ook in de rijke landen heerst er schaarste want daar moet men heel behoedzaam 'omspringen' met welzijn, gezondheid, schoon water, schone lucht en zelfs met tijd.

Zoals men van een wijsgerig werk mag verwachten wil Achterhuis niet 'zo maar' aantonen. Of beter uitgedrukt : zijn aantonen betekent tegelijk een begrijpelijk maken - misschien is bewijzen of verklaren te sterk uitgedrukt; daarop kan de wijsbegeerte uiteindelijk toch geen aanspraak maken. Achterhuis' 'begrippelijk' aantonen heeft een historische dimensie : hij gaat terug op het ontstaan van het moderne politieke denken dat we bij Thomas Hobbes moeten situeren. De auteur van de Leviathan is immers de eerste denker die, zonder dit woord te gebruiken, aldus Achterhuis, het moderne begrip van de schaarste systematisch ontwikkelt. Daarom kan men van de grootheid van Hobbes spreken.

"Mensen schijnen niet uit zichzelf, vanuit hun natuur automatisch naar meer macht te streven. Neen, het zijn de andere mensen, de maatschappelijke instituties die hen ertoe dwingen om op straffe van ondergang aan de concurrentierace deel te nemen. (...). Omdat bepaalde mensen hun macht verder uitbreiden dan voor hun veiligheid en welzijn nodig is, 'moeten anderen, die anders binnen bescheiden grenzen tevreden waren geweest, hun macht eveneens door agressie vergroten; als zij zich alleen bleven verdedigen, zouden zij niet lang kunnen overleven'" (blz. 62). Hiermee wil Achterhuis aantonen dat Hobbes duidelijk het mechanisme van de werking van de schaarste heeft onderkend : het heeft een dubbele dimensie : een maatschappelijke en een psychologische.

In de loop van de geschiedenis krijgen we nu auteurs die de klemtoon meer op de psychologische dimensie leggen - men kan in de eerste instantie aan Freud denken - terwijl anderen de maatschappelijke dimensie in de verf zetten. Eigenlijk behoort Achterhuis, als sociaal filosoof, eerder tot deze tweede categorie. Hij blijft hierin wel genuanceerd; hij laat zich daarenboven corrigeren door zijn inspiratie bij Rene Girard te zoeken. Van deze laatste leert hij immers wat de maatschappelijke werkzaamheid van de mimesis of nabootsing uitmaakt : "Het is kenmerkend voor mensen dat ze elkaar imiteren. In deze nabootsing ligt (...) zelfs de corsprong van de menselijke cultuur. De nabootsing wordt echter gevaarlijk in de 'mimetische begeerte'. Dit is precies het soort van begeerte waar Hobbes van uitgaat; mensen begeren dan bij voorkeur hetzelfde als dat wat een ander begeert. Het verhaal 
van Kaïn en Abel is voor Girard naast andere, bijvoorbeeld dat van Romulus en Remus, én van de oermythen van de mimetische begeerte." (blz. 39). Hieruit blijkt natuurlijk de zogenaamde subjectieve factor. De schaarste bestaat niet op zichzelf, maar wordt steeds op de een of de andere manier ter sprake gebracht en is daarenboven met waarderingen en gevoelens verbonden. Eigenlijk moet men niet zover zoeken; mensen zijn ontevreden, vinden dat ze steeds tekort hebben, zien dat anderen meer hebben of andere dingen bezitten; $z e$ willen zijn zoals die anderen, maar naarmate dat zij in die 'mimetische begeerte' gefrustreerd worden, gaan ze de anderen hun bezit benijden en zijn ze jegens die anderen afgunstig : zij gunnen de anderen hun bezit niet. De uiterste grens van deze afgunst wordt moord - Kaïn vermoordt Abel. (Hier kan men trouwens zeggen dat Kaïns jaloersheid - God bemint hem niet, wel zijn broer - in afgunst omslaat : aangezien God z'n broer Abel bemint en deze de liefde heeft die hij, Kain, niet kent, gunt deze z'n broer niet langer dit leven). Het lijkt gewettigd de subjectieve tegenpool van de 'objectieve' schaarste in de afgunst te zoeken. Ik heb echter de indruk dat Achterhuis dit aspect niet steeds doordrukt; dit kan trouwens ook niet. Hij legt, zoals al gezegd, in de eerste instantie de nadruk op het economische en sociale, om de eenvoudige reden dat het al te gemakkelijk zou zijn het slachtoffer van de schaarste door de overvloed van de andere steeds maar van afgunst te betichten. Er bestaat met andere woorden een onrechtvaardig en niet te rechtvaardigen bezit. Precies dit hebben veroorzaakt niet zelden een ondraaglijke schaarste. Grote bijdragen uit de geschiedenis van het politieke denken hebben de nefaste gevolgen van de materiele (en politieke) ongelijkheid willen inperken en regelen. Maar het succes is niet groot geweest, de gevaren van de 'mimetische begeerte' zijn niet verdwenen, integendeel, en de jongste ontwikkelingen in de Noord-Zuid-tegenstelling verraden een groeiende schaarste die miljoenen levens kost, tientallen beschavingen en honderden maatschappijen ontwricht.

Men kan zich dus afvragen : wat hebben de staatsorganisaties, wat heeft de cultuur met de menselijke 'natuur' aangevangen ? Uiteraard komt men dan bij het denken van Rousseau, van Marx en van Foucault terecht, en bij al diegenen die met deze grote figuren uit de sociale filosofie de problemen van hun tijd hebben willen begrijpen en oplossen. Achterhuis gaat in dat verband zelf in op twee belangrijke vraagstukken van onze tijd : de organisatie van de gezondheidszorg tegen de achtergrond van de spanning tussen technologische overvloed en schaarse financiële en technische toepassingsmodaliteiten; vervolgens het gigantische probleem van de honger in die wereld die economisch nagenoeg volledig van de handelsprioriteiten van de Westerse wereld afhankelijk is.

Opnieuw geïnspreerd door Hobbes schrijft Achterhuis over de schaarste op vitaal niveau heel treffend : "De zekerheidsbehoefte is in drie opzichten onverzadigbaar en dus schaarsteverwekkend. In de eerste plaats omdat mensen hier iets na- 
streven dat nooit verkregen kan worden, namelijk een van de dood afgescheiden leven. In de tweede plaats is deze behoefte nooit te bevredigen, omdat de risico's waaraan het menselijk leven blootgesteld is, oneindig zijn. Volledige zekerheid en bescherming zijn in principe onbereikbaar. Tenslotte is deze behoefte onverzadigbaar, omdat ze op vergelijking, op langer leven dan anderen, berust. Het vergelijkende principe drijft deze behoefte in een eindeloze jacht voorwaarts, een jacht die de heerschappij van de schaarste niet bestrijdt, maar juist meer en meer bevestigt" (blz. 284).

In het slothoofdstuk 'Honger. Het verborgen geweld' heeft Achterhuis het over de rampzalige situatie die gecreserd werd door de opdringerigheid van het Westerse model (die de 'mimetische begeerte' in de hand heeft gewerkt), maar daarenboven de Derde Wereld een produktie- en consumptiemodel heeft opgedrongen dat de bestaande cultuur en traditie volledig heeft ontwricht. Geïnspireerd door Rousseau schrijft de auteur van Het rijk van de schaarste : "Het Westen is erin geslaagd de meeste andere culturen zo te verwoesten en uit te hollen, dat het onderhand wel als navolgenswaardig voorbeeld verschijnt. De veelheid van traditionele culturen is vervangen door het ene model van de moderniteit. De wereldruimte die gevuld was met de meest verschillende varietteiten, die onderling van elkaar afgegrensd waren, is leeg en eenvormig geworden. Rousseau stelde dat de wilden doorzagen waar het in Europa om draaide : 'het voor zichzelf beschikken over de gemakken des levens (een letterlijke vertaling van het commodious living van Hobbes) en in aanzien staan bij anderen'. Zij mogen het toen afgewezen hebben; op dit moment is er de derde wereld alles aan gelegen dit te bereiken" (blz. 332) en dit op kosten van diegenen die al arm zijn, zo mogen we deze vaststelling aanvullen.

Hans Achterhuis heeft niet alleen een lijvig, maar ook een degelijk boek geschreven. Hij heeft een bepaalde gedachte, de schaarste, historisch en systematisch doordacht - op gevaar af zich aan systeemdwang te bezondigen - en tegelijk in een zo ruim mogelijk vakfilosofisch en maatschappelijk kader gesitueerd. Hij heeft zijn stelling duidelijk omschreven en gearticuleerd. Dat hij niet aan een geloofwaardige oplossing voor de honger toekomt, kan toch niemand hem kwalijk nemen. Filosofen veranderen de wereld wel door hem te interpreteren, maar lossen immers de wereldproblemen niet op, omdat zij, zoals niemand anders trouwens (gelukkig genoeg), die almacht daartoe niet hebben. 